American J. of Engineering and Applied Sciences 4 (2): 270-275, 2011

ISSN 1941-7020

(C) 2011 Science Publications

\title{
Utilizing Geographic Information System for Prediction of Soil Erosion in Sono Sragen Catchment Area
}

\author{
${ }^{1,2}$ Muhammad Mukhlisin and ${ }^{3}$ Sukoco \\ ${ }^{1}$ Department of Civil and Structural Engineering, \\ Faculty of Engineering and Built Environment, \\ University Kebangsaan, Malaysia \\ ${ }^{2}$ Department of Civil Engineering, Polytechnic Negeri Semarang, \\ ${ }^{3}$ Department of Information Engineering, University Surakarta, Indonesia
}

\begin{abstract}
Problem statement: Embung is a small dam created by manmade lakes and used to catch water during rainy season for an irrigation source. In Sragen area, Embung Sono is one of around twenty embung that used to catch rain water for irrigation. Soil erosions in catchment area are potential to reduce water capacity of the embung. Although many embung have been constructed in Sragen areas, the numbers of soil erosion in catchment area of embung are not well considered. Approach: Soil erosion in the Sono catchment area was analyzed using Geographic Information System (GIS) and Universal Soil Loss Equation (USLE) method. Results: The result showed that total number of soil erosion in the Sono catchment area is 63.50 ton/ha-year and categorized in moderate classified. Value of Sediment Delivery Ratio (SDR) for catchment was 0.34. Empirical equation proposed by Renfro, Vanoni and USDA were also used to analyze the SDR value. Conclusion: It was found that USDA is the best method that can be used to predict soil erosion in Sragen area. It means the crop management and environmental conservation in Sono catchment need to be improved.
\end{abstract}

Key words: Geographic Information System (GIS), erosion, sragen area, Universal Soil Loss Equation (USLE), empirical equation, Sediment Delivery Ratio (SDR)

\section{INTRODUCTION}

Water is very important to human being and living things. Human civilization will not reach like now, without developing water resources consistently. Therefore developing and managing water resources are base of human civilization. In rainy season, the excessive rain water can cause flood. On the other hand, in dry season, there is a little water that will cause dryness. To solve dryness in dry season, the cheaper strategy is water harvesting. Water harvesting effort coincide with improve water saving in river, dam and lake; all can preserve water supplies for farming, domestic and industries. An effort to manage excessive rain water is to build embung (onfarm reservoir). Embung is one simple technology, relative cheap and achievable by farmer society.

The main problem in using embung technology is excessive erosion that will make sedimentation within embung. Soil erosion caused moving soil particle to other place or sediment transportation. Particle soil transportation in the channel is being another problem concerned with erosion. Therefore there are many problem can be found due to sedimentation in river and dam in all of the word (e.g., Abu Hammad, 2010 and Schönbrodt et al., 2010). The effect of soil erosion is very serious; it's not only in Indonesia, but in the other country such as in west China, leading to heavy sediment load in many rivers (Suo, 2004) and also in Southern Neka Basin in Iran (Solaimani et al., 2009). In their studies, Narioka et al (2001) concluded that the erosion degree in the area ranges from very slight to very severe, depending on land status, while Lee and Lee (2010) explained that the result of simulation depending on model selection and measurement accuracy. Erosion occurred slightly in the forestland, but it was severe in the dry lands with slope more than $15 \%$. To achieve sustainable farming in the slope lands, effective conservation measures combined with soil surface protection and appropriate cropping pattern should be establish in the tropical volcanic highland.

Scale of erosion vary in many places and depends on many factors. Result analysis showed that erosion in Buyan Lake Bali watershed dominated by erosion <2 ton $\mathrm{h}^{-1}$ year $^{-1}$ in area $720 \mathrm{~h}$ or $37.091 \%$ of watershed area. In Candikuning, Bali, erosion prediction is

Corresponding author: Muhammad Mukhlisin, Department of Civil and Structural Engineering, Faculty Engineering and Built Environment, Universiti Kebangsaan Malaysia, Bangi, Selangor, Malaysia 
between 2.82-871.52 ton $\mathrm{ha}^{-1}$ year ${ }^{-1}$. Erosion varied from very slight to severe, depends on land condition. Erosion was found to occur slightly in the forestland but was more severe in the dry and shrub lands especially in areas with slope more than $15 \%$ (Narioka et al., 2001).

Embung is a solution for solve the irrigation problem during rainy season. On the other hand soil erosions in watershed are potential to reduce water capacity of the embung. Many previous studies (e.g., Suo, 2004; Narioka et al., 2001) showed that significant effect of soil erosion is depending on many parameters (e.g., soil type, slope area and land use area). Many local governments in Indonesia such as Sragen, Surakarta, Ungaran in Central Jawa have been developing many embung in order to irrigate the farmer area. In contrast, there is view study about effect of erosion to capacity of embung storage.

In addition, GIS technologies could provide a powerful tool to model the soil erosion for their spatial analysis and prediction. Many previous (e.g., Lufafa et al., 2003; Hasmadi et al., 2010 and Mukhlisin et al., 2010) studies explained that by using GIS the collection, manipulation and analysis of the environmental data on soil erosion can be done much more efficiently. In this study we proposed a method to analyze the potential of soil erosion soil erosion in the Sono catchment Sragen using Geographic Information System (GIS) combining with Universal Soil Loss Equation (USLE) method. Result of this analysis then used to calculate the value of Sediment Delivery Ratio (SDR) and compared with empirical equation proposed by Renfro, Vanoni and USDA.

\section{MATERIALS AND METHODS}

Study area: Embung Kedung Sono is one of around twenty embung in Sragen, Central Jawa that have been used to catch rain water for irrigation (Fig. 1 and 2). Sono catchment covers area in Pengkok, Celep, Karangpelem, Mojodoyong, Jenggrik and Kuto village and located between $110^{\circ} 59^{\prime} 0.44^{\prime \prime} \mathrm{E}$ and $111^{\circ} 2$ ' $54^{\prime \prime} \mathrm{E}$ as well as between $7^{\circ} 32,25^{\prime} \mathrm{S}$ and $7^{\circ} 29,5$ " S. The area, length and slope average of Sono catchment are $1.112 \mathrm{~h}$; $9.360 \mathrm{~m}$ and $2.2 \%$, respectively. The elevation of the catchment is between $324 \mathrm{~m}$ and $112.5 \mathrm{~m}$ asl. Sono catchment area has been used mostly for wet rice crop. Geologycal stucture of Sono watershed is Lawu mountain deposit: volcanic sandstone, volcanic siltclaystone, volcanic breccia and lava.

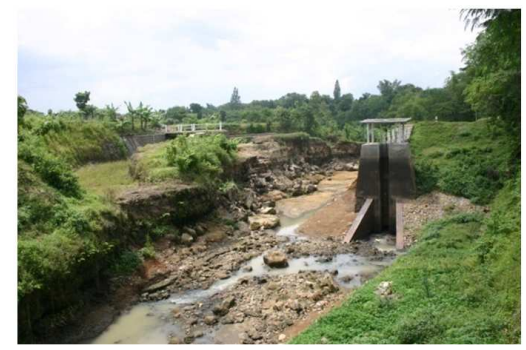

(a)

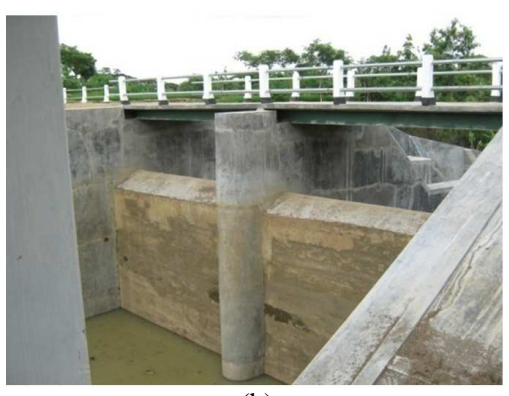

(b)

Fig. 1: Embung Kedung Sono (a) before and (b) after rebuild

Figure 2 shows Sono catchment area located in Sragen, Central Jawa. Embung Kedung Sono, Pengkok, Sragen located in $7^{\circ} 29^{\prime}$ 6" $\mathrm{S}$ and $110^{\circ} 59^{\prime} 10^{\prime \prime} \mathrm{E}$. Embung Kedung Sono can be used to irrigate rice field around Pengkok village. With availability of these embung the production of rice crop and the people economic grade can be increased.

USLE: Universal Soil Loss Equation (USLE) is the most widely used of all soil erosion models. USLE was designed to predict soil loss from surface soil with respect to land use area (e.g., soil type, vegetation and management). USLE equation was designed to predict long-term average annual soil loss (Risse et al., 1993).

Simplification of the complex reality in a catchment is required to analyze utilizing the model. Decisions need to be made on a suitable level of complexity or simplicity depending on the objective (Morgan, 2005). Soil erosion in a catchment area will reduce soil productivity and causes a loss of reservoir capacity. The well-known Universal Soil Loss Equation (USLE) represents a standardized approach (Zhou and $\mathrm{Wu}, 2008$ ).

An USLE method is commonly used to predict erosion. The USLE is simple and very good to be implemented to area which has main factor erosion is rain water and run off (Schönbrodt et al., 2010). 


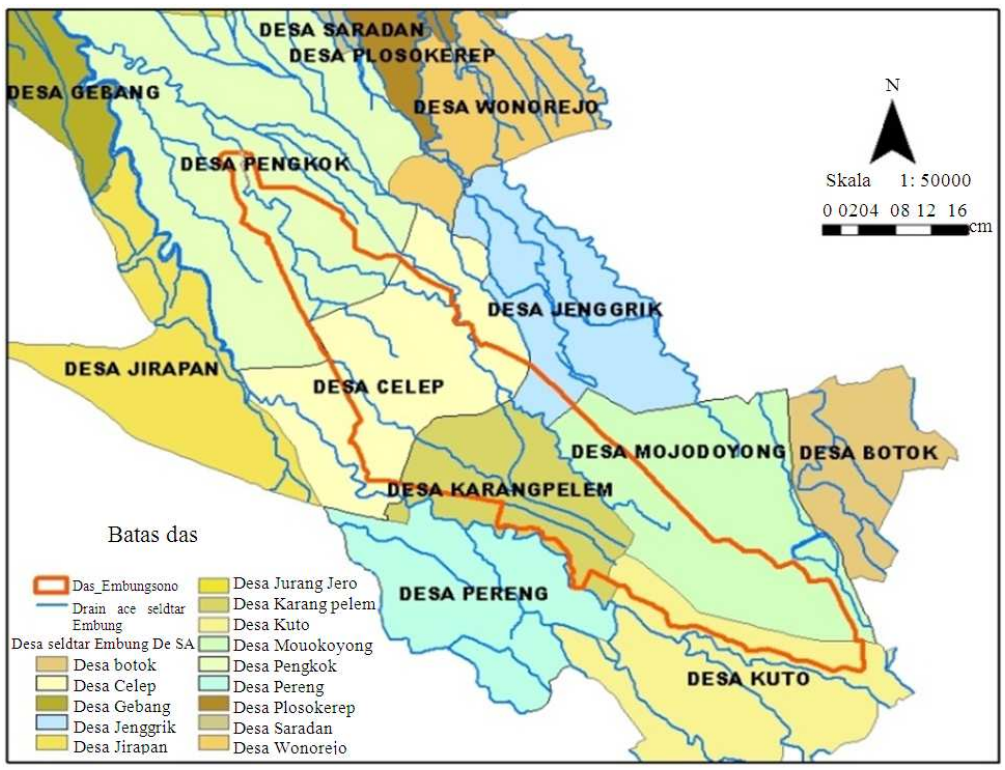

Fig. 2: Sono catchment area boundary

The USLE's equation is:

$\mathrm{E}=\mathrm{R} * \mathrm{~K} * \mathrm{~L} * \mathrm{~S} * \mathrm{C} * \mathrm{P}$

$\mathrm{E}=$ Mean annual soil loss

$\mathrm{R}=$ Rainfall erosivity factor

$\mathrm{K}=$ Soil erodibility factor

$\mathrm{L}=$ Slope length factor

$\mathrm{S}=$ Slope steepness factor

$\mathrm{C}=$ Crop management factor

$\mathrm{P}=$ Erosion-control practice factor

Sediment Delivery Ratio (SDR): Sediment prediction can be done by calculating SDR. SDR calculation is important for realistic prediction of total sedimentation base on erosion calculation in watershed.

Accurate prediction of sediment delivery ratio is an important and effective approach to predict sediment yield which is usually not measured. Presently available prediction models are not generally applicable to a particular watershed (Ouyang and Bartholic, 1997).

Drainage area approach: The relationships between SDR and other factors have been established as curves. Watersheds with large drainage area and the fields with a long distance to the streams have a low sediment delivery ratio.

As reported on (Ouyang and Bartholic, 1997), Renfro developed an equation relating SDR with the drainage area. It is based on Manner's equation and the sediment yields observed in 14 watersheds in the
Backland Prairie Area in Texas. The model shows a good relationship between SDR and the drainage area $\left(R^{2}=0.92\right)$. The model can be written as follows:

$\log (\mathrm{SDR})=1.7935-0.14191 \log (\mathrm{A})$

where, $\mathrm{A}=$ drainage area in $\mathrm{km}^{2}$ Valona used the data from 300 watersheds throughout the world to develop a model by the power function. This model is considered a more generalized one to estimate SDR:

$\mathrm{SDR}=0.42 \mathrm{~A}^{-0.125}$

where, A, drainage area in square miles.

The USDA SCS developed a SDR model based on the data from the Blackland Prairie, Texas. A power function is derived from the graphed data points:

$\mathrm{SDR}=0.51 \mathrm{~A}^{-0.11}$

where, A, drainage area in square miles.

Slope, gradient and relief-length ratio: SDR is affected by the topographic features of the watershed. A watershed with short and steep slopes will deliver more sediment to a channel than a watershed with a long and flat landscape.

Ouyang and Bartholic (1997) explained that Williams and Berndt's used slope of the main stream channel to predict sediment delivery ratio. The model is written as: 
$\operatorname{SDR}=0.627$ SLP 0.403

where, SLP, \% slope of main stream channel.

Manner's studies suggested that SDR was better correlated with relief and maximum length of a watershed expressed as Relief-Length ratio $(\mathrm{R} / \mathrm{L})$ than with other factors. Renfro 1975 modified the model $\left(\mathrm{R}^{2}\right.$ $=0.97$ ) as follows:

$\log (\mathrm{SDR})=2.94259+0.82362 \log (\mathrm{R} / \mathrm{L})$

where, R, relief of a watershed, defined as the difference in elevation between the average elevation of the watershed divide and the watershed outlet. $\mathrm{L}=$ maximum length of a watershed, measured approximately parallel to mainstream drainage.

\section{RESULTS}

Ruster Method was applied to be used to analysis the potensial erosion in the catchment area. For each factores in the USLE method such as the rainfall erosivity (R), soil erodibility (K), crop management C), length of slope (L), steepness of the slope (S) and the erosion control practice factors were modeled in builder model with sieze for each sel $20 \times 20 \mathrm{~m}$.

The rainfall erosivity was anayzed using 14 years rainfall data from two raingauge stations. For soil erodibility was analyzed based on 15 samples which collected from the entire catchment area (Fig. 3). Figure 4 shows LS factor thas was analyzed from topography map with scale 1:25,000. While Fig. 5 and 6 show the map fo crop management and erosion control practice, respectively that were analyzed absed observed land survey.

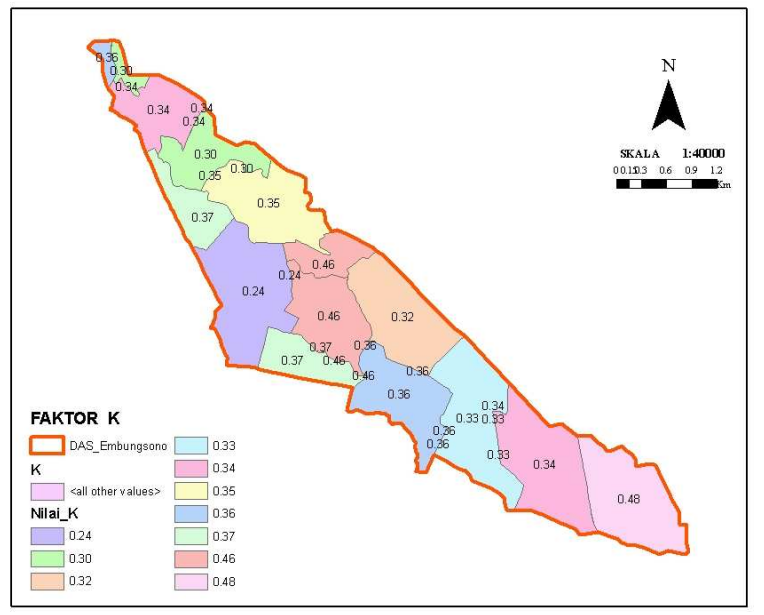

Fig. 3: Map of soil erodibility (K factor)

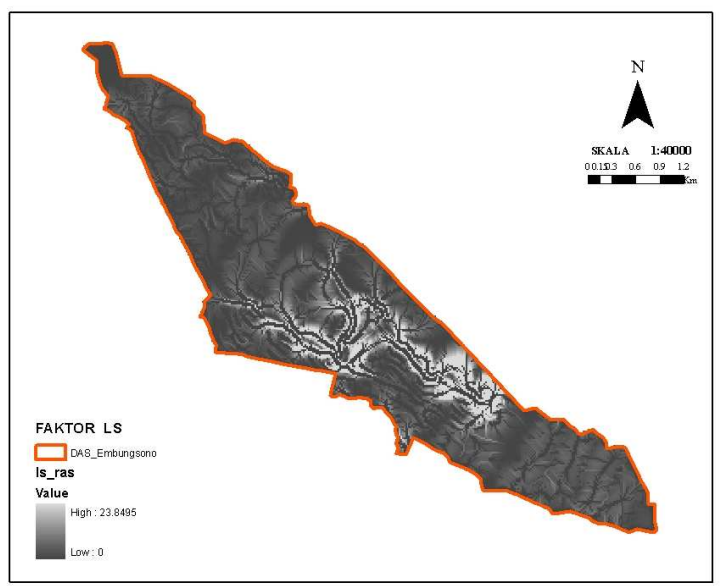

Fig. 4: Map of length and steepness of the slope (LS factor)

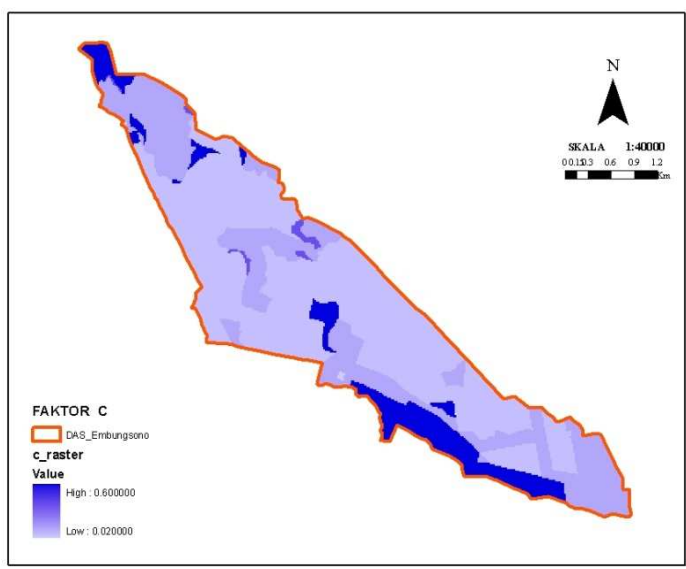

Fig. 5: Map of crop management ( $\mathrm{C}$ factor)

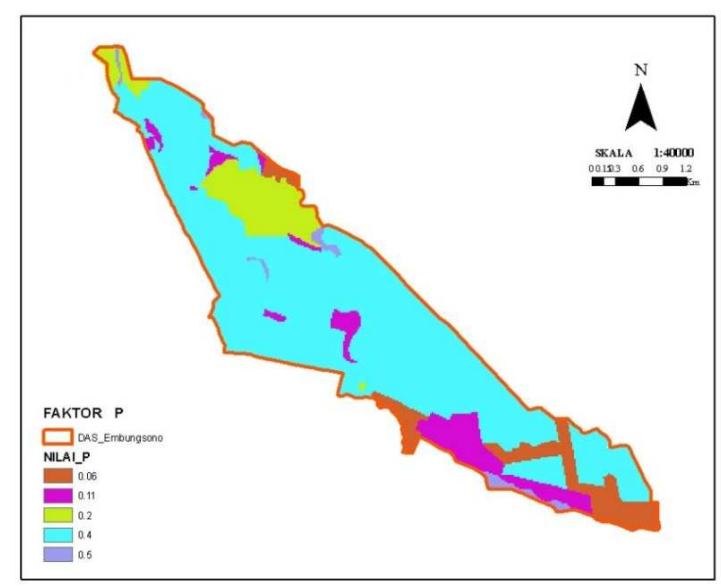

Fig. 6: Map of Erosion-control practice (P factor) 


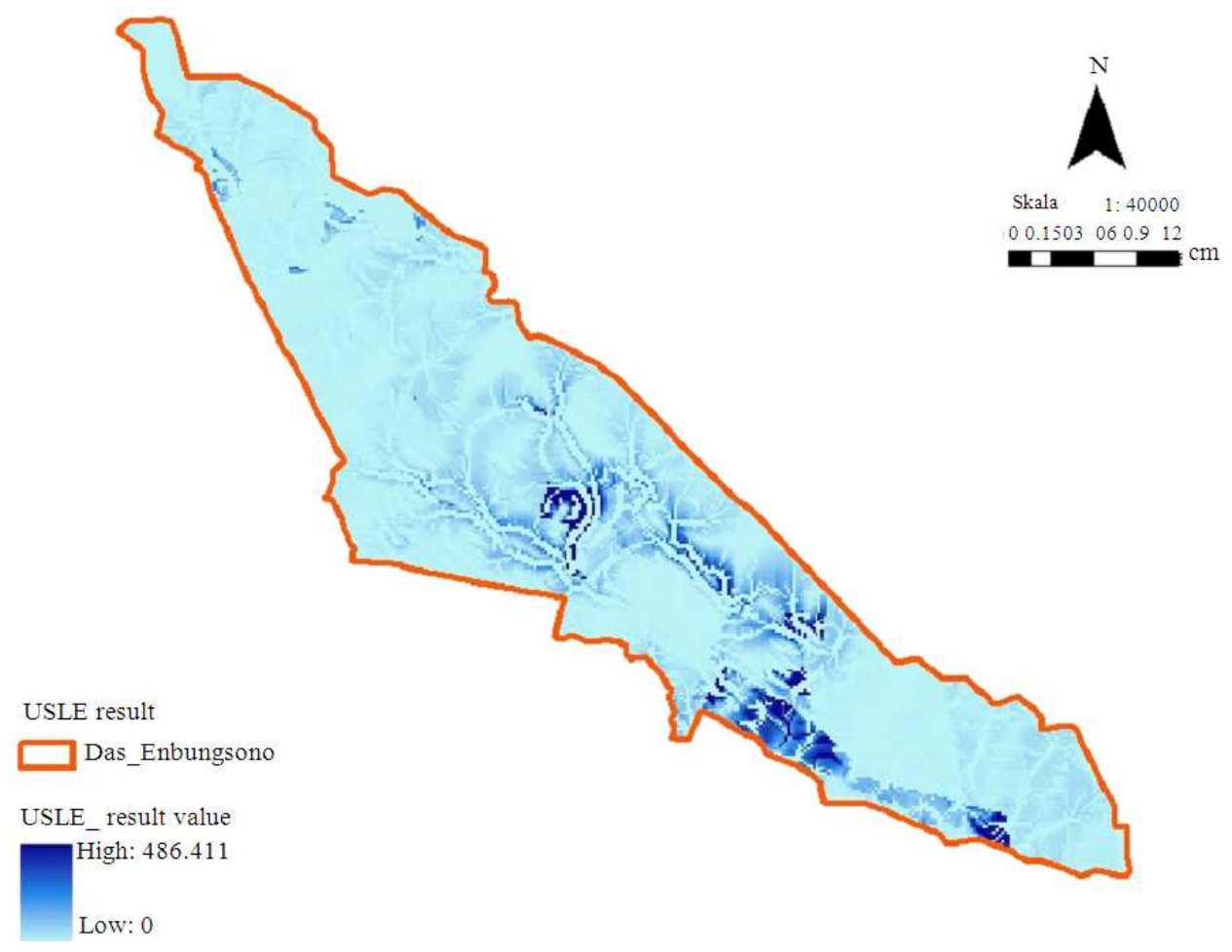

Fig. 7: Mapping of annual soil loss by USLE Result raster

\section{DISCUSSION}

Figure 7 shows the model that was used to calculate erosion in catchment area using USLE's Eq. 1. From the figure can be seen that professeive erossion occured on some part of the catchment, particularly on step slope.

USLE_Result from the modeling is in image condition and there is not show the amount of soil erosion. Using zonal statistic function in Arc Gis, mean annual of soil erosion can be calculated as follows:

- $\quad$ Mean annual erosion $=70.524,24$ ton $_{\text {year }}{ }^{-1}$

- Mean annual erosion $/ \mathrm{h}=63.50$ ton/(h year)

- Volume Mean annual erosion $=34.069,68 \mathrm{~m}^{3}$ year $^{-1}$

- Mean annual height soil that erosion $=0.31 \mathrm{~cm}$ year $^{-1}$

- Watershed area $=11.12 \mathrm{~km}^{2}=1,111.87 \mathrm{~h}$

Using Eq. 2, 3, 4, 5 and 6 SDR can be analyzed. The SDR value of each method can be seen on Table 1. The Table 1 shows that number of soil erosion in the range from 0.26-0.44, except Williams and Berndt's method.
Table 1: SDR value using some methods

\begin{tabular}{lll} 
Table 1: SDR value using some methods & SDR \\
\hline Approach & Method & 0,44 \\
Drainage area & Renfro (RA) & \\
Vanoni & 0,26 & \\
The USDA SCS & 0,33 & 0,86 \\
Slope, gradient & Williams and Berndt's & \\
Renfro (R/L) & 0,37 & \\
\hline
\end{tabular}

\section{CONCLUSION}

In this study can be analyzed that total number of soil erosion in the Sono catchment area is 63.50 ton $^{-1}$ year. Regarding Indonesian Forestry ministry's soil lost classification Sono catchment can be categorized to moderate erosion. It means the crop management and environmental conservation in Sono catchment need to be improved. In addition, the value of Sediment Delivery Ratio (SDR) for the catchment is 0.34 . Empirical equation proposed by Renfro, Vanoni and USDA were also used to analyze the SDR value. It was found that USDA is the best method that can be used to predict soil erosion in the Sragen area.

\section{REFERENCES}

Abu Hammad, A., 2010. Watershed erosion risk assessment and management utilizing revised universal soil loss equation-geographic information systems in the Mediterranean environments. 15: 834-843 DOI: 10.1061/(ASCE)HE.19435584.0000254 
Hasmadi, I.M., H.Z. Pakhriazad and F.S. Mohamad, 2010. Geographic Information System-Allocation Model for Forest Path: A Case Study in Ayer Hitam Forest Reserve, Malaysia. Am. J. Applied Sci., 7: 376-380. DOI: 10.3844/.2010.376.380

Lee, G.S and K.H. Lee, 2010. Determining the sediment delivery ratio using the sediment-rating curve and a geographic information systemembedded soil erosion model on a basin scale. J. Hydrol. $\quad$ Eng., 15: 834-843. DOI: 10.1061/(ASCE)HE.1943-5584.0000254

Lufafa, A., M.M. Tenywa, M. Isabirye, M.J.G. Majaliwa and P.L. Woomer, 2003. Prediction of soil erosion in a Lake Victoria basin catchment using a GIS-based Universal Soil Loss model. Agric. Syst., 76: 883-894. DOI: 10.1016/S0308521X(02)00012-4

Morgan, R.P.C., 2005. Soil Erosion and Conservation. 3rd Edn., Blackwell Publishing, Oxford, ISBN: 1405117818, 9781405117814, pp: 304.

Mukhlisin, M., I. Idris, A. Salazar, K. Nizam and M.R. Taha, 2010. GIS based landslide hazard mapping prediction in ulu klang. Malaysia, ITB J. Sci., 42: 163-178.

http://www.scopus.com/source/sourceInfo.url?sour ceId $=17700156311$

Narioka, H., A.I.W.S. Mastur and S.M. Medina, 2001. Land characteristics and soil erosion in relation to slope farming in the highlands of candikuning, Bali, Indonesia. J. Jpn Soc. Soil Phys., 87: 37-45. http://soil.en.a.u-okyo.ac.jp/jssp/db/pdf/087037.pdf

Ouyang, D. and J. Bartholic, 1997. Predicting sediment delivery ratio in saginaw bay watershed. Proceedings of the 22nd National Association of Environmental Professionals Conference, May 1923, 1997, Orlando FL. pp: 659-671. http://www.iwr.msu.edu/\% 7Eouyangda/sdr/sagsdr.htm http://www.iwr.msu.edu/ ouyangda/sdr/sdr.htm
Risse, L.M., M.A. Nearing, A.D. Nicks and J.M. Laflen, 1993. Error assessment in the universal soil loss equation. Soil Sci. Soc. Am. J., 57:

825-833. http://www.tucson.ars.ag.gov/unit/publications/PD Ffiles/MAN_16.pdf

Schönbrodt, S., P. Saumer, T. Behrens, C. Seeber and T. Scholten, 2010. Assessing the USLE crop and management factor $\mathrm{C}$ for soil erosion modeling in a large mountainous watershed in Central China. J. Earth Sci., 21: 835-845. DOI: 10.1007/s12583-0100135-8

Solaimani, K., S. Modallaldoust and S. Lotfi, 2009. Soil erosion prediction based on land use changes (a case in neka watershed). Am. J. Agric. Biol. Sci., 4: 97-104. DOI: 10.3844/ajabssp.2009.97.104

Suo, L., 2004. River management and ecosystem conservation in China. Proceeding of the 9th International Symposium On River Sedimentation, Oct. 18-21, Yichang, China, pp: 1-10. http://www.irtces.org/old/irtces/report/9isrs/Lishen gSuo.pdf

Zhou, W. and B. Wu, 2008. Assessment of soil erosion and sediment delivery ratio using remote sensing and GIS: A case study of upstream Chaobaihe River catchment, north China. Int. J. Sediment Res., 23: 167-173. DOI:10.1016/S10016279(08)60016-5 